\title{
Inovasi Produk Bubuk Cincau Hijau Berbasis Daya Terima Konsumen
}

\author{
Hananul Umumah ${ }^{1}$, Woro Priatini ${ }^{1}$, Christian H. Rumayar ${ }^{2}$ \\ ${ }^{1}$ Manajemen Industri Katering, Fakultas Pendidikan Ilmu Pengetahuan Sosial, Universitas \\ Pendidikan Indonesia, Jl. Dr. Setiabudhi No. 229, Bandung 40154, Indonesia \\ ${ }^{2}$ Food and Beverage Service, Sekolah Tinggi Pariwisata Bandung, Jl. Dr. Setiabudi No.186, \\ Hegarmanah, Kec. Cidadap, Kota Bandung, Jawa Barat 40141 \\ *Koresponding Penulis. E-mail : hananulu@gmail.com (Hananul Umumah)
}

\begin{abstract}
Abstrak
Penelitian ini bertujuan untuk menentukan formulasi resep, daya terima konsumen, dan harga jual untuk produk ini. Penelitian ini menggunakan metode eksperimen kuantitatif. Ada dua langkah dalam penelitian ini, langkah pertama adalah uji organoleptik terhadap 15 panelis profesional, dengan memberi mereka empat sampel produk Bubuk Cincau Hijau untuk mendapatkan yang terbaik dengan perbandingan formulasi BCHAA1 (Serbuk Agar 40\%), BCHAA2 (Bubuk Agar) 60\%), BCHJ1 (bubuk Jelly $40 \%$ ), dan BCHJ2 (bubuk Jelly $60 \%$ ), dan hasilnya menunjukkan bahwa BCHJ1 adalah produk terbaik. Kemudian produk BCHJ1 digunakan pada langkah kedua, penilaian uji penerimaan konsumen terhadap 100 panelis konsumen. Skor hasil untuk Bubuk Cincau Hijau adalah 3119, berada pada skala interval kelas 2721 - 3360, di mana skala menunjukkan bahwa produk diterima oleh panelis konsumen. Perhitungan harga jual Bubuk Cincau Hijau adalah Rp. 6.000 / sachet.
\end{abstract}

Kata Kunci: Inovasi produk; Bubuk Cincau Hijau; Bubuk Agar; Tes Organoleptik; Daya Terima Konsumen.

\section{Pendahuluan}

Cincau adalah nama tumbuhan yang dapat membentuk gel serupa agar-agar yang diperoleh dari perendaman daun (atau organ lain) tumbuhan tertentu dalam air. Gel terbentuk karena daun tumbuhan tersebut mengandung karbohidrat yang mampu mengikat molekul-molekul air. Cincau paling banyak digunakan sebagai komponen utama minuman penyegar (misalnya dalam es cincau atau es campur). Ada 4 jenis tanaman yang umum digunakan sebagai bahan pembuat cincau yaitu cincau hijau (Cyclea barbata), cincau perdu (Premna Serratofila), cincau hitam (Mesona Palustris), dan cincau minyak (Stephania hermandifolia) (Pitojo, S. , \& Sumiati, 2005, hlm. 1)

Cincau hijau dan hitam terbuat dari tanaman yang berbeda, keduanya pun memiliki manfaatnya masing-masing. Bila cincau hijau memiliki manfaat kesehatan seperti meredakan radang tenggorokan dan menjaga tekanan darah agar tetap stabil. Sementara cincau hitam yang kaya akan serat baik untuk kelancaran pencernaan dan membuat rasa kenyang bertahan lebih lama.

Untuk pembuatannya pun terdapat perbedaan di antara keduanya, cincau hijau terbilang lebih mudah dibuat. Hanya perlu memetik beberapa lembar daun cincau hijau, lalu diremas bersama air matang hingga lendir dan sarinya keluar. Lalu disaring agar terpisah dari ampas daun, setelah itu didiamkan +/- 4 jam untuk siap disajikan. Walaupun pembuatannya cukup mudah, daya tahan cincau hijau itu sendiri memang tidak lama. Sedangkan untuk cincau hitam, pembuatannya terbilang cukup rumit, 
dimulai dari pengeringan daun cincau hitam, perebusan dengan abu merang hitam dan air, dan dimasak dengan air dan pati tapioka hingga mendidih, dan didiamkan semalaman agar mengeras.

Pra-penelitian ke lapangan dilakukan untuk melihat cincau hijau yang ada di pasaran saat ini. Hasilnya cincau hijau yang ada di pasaran sekarang merupakan produk cincau hijau siap santap tanpa keterangan batar kadaluarsa, kecuali yang dijual di supermarket (memiliki tanggal kadaluarsa 5-6 hari). Produk cincau hijau yang lainnya (tanpa tanggal kadaluarsa) menurut keterangan penjual dinyatakan hanya bertahan satu hari, setelah itu akan mencair dan tidak dapat dikunsumsi kembali.

Penelitian terdahulu mengenai cincau hijau juga sudah dilakukan oleh beberapa mahasiswa Manajemen Industri Katering tentang inovasi produk cincau hijau, yaitu pembuatan cincau hijau dengan penambahan bahan pengental, cincau hijau dengan kuah jahe, puding cincau hijau vla bir pletok, serta cincau hijau dengan saus tepung beras merah. Semua inovasi yang sudah dilakukan berfokus pada penyajian cincau hijau itu sendiri, tetapi dari segi daya tahan produk cincau hijau itu sendiri masih belum bisa bertahan lama. Hal inilah yang menjadikan penelitian bubuk cincau hijau berbasis daya terima konsumen.

Sebelum memulai penelitian, dilakukan pra-eksperimen pembuatan bubuk cincau hijau sebanyak dua kali. Praeksperimen pertama dilakukan untuk menemukan metode pengeringan yang sesuai dalam mengeringkan daun cincau hijau. Penulis melakukan pengeringan dengan tiga cara yang berbeda untuk mendapatkan hasil terbaik. Cara yang digunakan penulis untuk mengeringkan daun cincau hijau adalah menggunakan oven, disangrai, dan dijemur dibawah sinar matahari.

Pengeringan daun menggunakan oven penulis lakukan dengan suhu 100 oc dalam waktu +/- 10 menit, daun menjadi kering tetapi tidak merata sehingga beberapa daun harus dilakukan pemanasan ulang, namun tetap bisa dijadikan bubuk cincau setelahnya. Ketika disangrai, waktu yang dibutuhkan agak lama dan membutuhkan energi karena penulis harus terus menyangrai agar tidak gosong, namun hasilnya daun kering merata secara sempurna dan dapat dijadikan bubuk cincau. Penjemuran dibawah sinar matahari dilakukan lebih dari 2 hari karena kondisi cuaca di Kota Bandung yang sedang tidak terlalu cerah, daun cincau hijau menjadi layu (tidak kering) kemungkinan dikarenakan cuaca panas yang tidak stabil.

Penulis menyimpulkan untuk melanjutkan penelitian bubuk cincau hijau ini dengan metode pengeringan di sangrai, karena selain dibuktikan berhasil, daun cincau hijau juga dapat kering secara merata dibandingkan dengan menggunakan oven. Setelah daun cincau hijau segar dijadikan bubuk, komponen pembentuk gel yang terkandung di dalamnya, sudah hilang karena panas namun tidak menghilangkan rasa dan aroma cincau hijau itu sendiri. Sehingga, penulis melakukan praeksperimen kedua untuk menggantikan gel yang hilang dengan tambahan jeli, agaragar, dan gelatin.

Dalam pra-eksperimen ini penulis menambahkan bubuk jeli, bubuk agar-agar, serta bubuk gelatin ke dalam bubuk cincau hijau. Lalu dimasak dengan air hingga mendidih. Hasilnya, cincau hijau dengan tambahan jeli memiliki tekstur yang lembut dan kenyal. Cincau hijau dengan tambahan agar-agar memiliki tekstur sedikit keras. Sedangkan cincau hijau dengan tambahan gelatin memiliki tekstur hampir mirip dengan cincau hijau dengan tambahan agaragar. Diantara cincau hijau dengan tambahan agar-agar dan gelatin, perbedaan terdapat pada warna yang dihasilkan, cincau hijau dengan tambahan agar-agar menghasilkan warna hijau yang lebih sesuai dengan aslinya, sedangkan cincau hijau dengan tambahan gelatin menghasilkan warna yang lebih pudar dan cenderung mengkilat. Penulis menyimpulkan untuk 
tidak melanjutkan penelitian menggunakan bubuk gelatin, karena tekstur yang dihasilkan tidak jauh berbeda dengan bubuk agar-agar dan memiliki warna yang pudar. Guna menemukan takaran yang sesuai dalam penggunaan bubuk agar-agar ataupun bubuk jeli, maka disusunlah penelitian dengan judul "Inovasi Produk Bubuk Cincau Hijau Berbasis Daya Terima Konsumen".

Berdasarkan latar belakang diatas, terbentuklah rumusan masalah sebagai berikut:

a. Bagaimana formulasi resep inovasi produk bubuk cincau hijau?

b. Bagaimana daya terima konsumen terhadap inovasi produk bubuk cincau hijau?

c. Bagaimana harga jual yang sesuai dengan inovasi produk bubuk cincau hijau?

Berdasarkan rumusan masalah, maka tujuan penulisan proposal skripsi ini adalah :

a. Untuk mengetahui formulasi resep inovasi produk bubuk cincau hijau.

b. Untuk mengetahui daya terima konsumen terhadap inovasi produk bubuk cincau hijau.

c. Untuk mengetahui harga jual yang sesuai dengan inovasi produk bubuk cincau.

Inovasi produk merupakan sebuah cara metode untuk menemukan sebuah produk yang sesuai dengan keinginan konsumen. Mengingat keinginan atau selera konsumen yang sering mengalami perubahan seiring berkembangnya teknologi dan persaingan, perusahaan tidak bisa jika hanya mengandalkan produk yang ada untuk menjalankan bisnisnya terus menerus. Sebuah inovasi dibutuhkan dalam hal ini, inovasi sendiri diartikan sebagai suatu ide, produk atau bagian dari suatu teknologi yang sudah dikembangkan dan kemudian dipasarkan kepada pelanggan yang dirasa sebagai sesuatu yang baru.

Menurut Dhewanto, Wawan (2014, hlm. 67) inovasi produk merupakan hasil dari pengembangan produk baru oleh

perusahaan atau industri, baik yang sudah ada maupun belum dengan tujuan untuk menjaga trend dan menghindari adanya titik jenuh yang dirasakan konsumen pada produk yang ditawarkan. Pada era saat ini konsumen menginginkan produk yang berkualitas serta unggul dengan harga yang terjangkau. Oleh karena itu produsen semakin gencar berinovasi menciptakan produk-produk yang sesuai dengan keinginan konsumen.

Menurut Pitojo, S. , \& Sumiati (2005, hlm. 1) ada 4 jenis tanaman yang umum digunakan sebagai bahan pembuat cincau yaitu cincau hijau (Cyclea barbata), cincau perdu (Premna Serratofila), cincau hitam (Mesona Palustris), dan cicncau minyak (Stephania hermandifolia). Dari keempat tanaman tersebut yang dikenal sebagai masyarakat adalah cincau hijau dan cincau perdu. Namun, cincau yang banyak digunakan adalah cincau hijau, cincau perdu dan cincau hitam. Cincau minyak hingga kini belum di temukan di pasaran umum. Cincau perdu biasanya dijual dalam bentuk es cincau.

Tanaman cincau perdu termasuk kedalam kelas tanaman tingkat tinggi. Tanaman cincau perdu ini berbunga, menghasilkan biji belah, dan termasuk suku jati-jatian. Kedudukan taksonomi cincau perdu digambarkan dalam tabel berikut :

Tabel 1. Taksonomi Cincau Perdu

\begin{tabular}{ll}
\hline $\begin{array}{l}\text { Divisio } \\
\text { Subdivisio }\end{array}$ & $\begin{array}{l}\text { Spermatophyta } \\
\text { Angiospermae } \\
\text { Classis }\end{array}$ \\
$\begin{array}{l}\text { Dicotyledonae } \\
\text { Familia }\end{array}$ & $\begin{array}{l}\text { Lamiales } \\
\text { Verbenaceae } \\
\text { Genus }\end{array}$ \\
$\begin{array}{l}\text { Premna } \\
\text { premna serratifolia L. sinonim } \\
\text { premna integrifolia L/ premna } \\
\text { obtusifolia } \text { R/Br. }\end{array}$ \\
Sumber: Khasiat Cincau Perdu, Setijo (2008, hlm. 11) \\
Tanaman cincau perdu ini termasuk \\
kedalam tanaman sempurna, yaitu memiliki \\
akar, batang, cabang daun, bunga, dan buah \\
yang menghasilkan biji. Bagian tanaman \\
cincau perdu yang digunakan untuk \\
membuat olahan minuman cincau adalah \\
daunnya.
\end{tabular}


Daun cincau perdu terletak berpasangan dan berhadapan, bersilang pada batang dan cabang serta ranting tanaman. Daun cincau perdu menyirip genap. Helaian daun tipis, kaku, seperti kulit belulang. Daun berbentuk bulat telur, ujung dan pangkalnya lancip, tepi daun rata. Tulang daun melengkung, daun bagian atas licin gundul, getas, dan berwarna hijau berkilat, sedangkan bagian bawah berwarna hijau muda. Daun yang telah berwarna kuning. Panjang daun $20 \mathrm{~cm}$ dan lebar $13 \mathrm{~cm}$, sedangkan panjang tangkai daun sekitar 2 cm bobot 190 lembar daun cincau perdu normal yang telah layak pakai sekitar satu kilogram. (Pitojo, S., 2008, hlm. 12-17).

Cincau mengandung beragam manfaat bagi kesehatan. Cincau perdu misalnya, dimanfaatkan untuk mengobati penyakit tekanan darah tinggi. Cincau rambat dimanfaatkan sebagai obat anti demam, penurunan tekanan darah tinggi. Demikian juga cincau hitam selain untuk hal-hal serupa diatas juga bisa meredakan panas dalam dan radang tenggorokan. Dengan demikian inilah beberapa manfaat dari cincau menurut Hariana, Arief (2013 hlm. 93), yaitu:

a. Mencegah demam, dan menurunkan tekanan darah. Efek farmakologis cincau rambat diantaranya, anti demam, anti racun, dan menurunkan tekanan darah.

b. Mengobati radang lambung, tifus dan penyakit usus.

Tabel 2. Kandungan Nutrisi dalam 100 Gram Daun Cincau

\begin{tabular}{lc}
\hline \multicolumn{1}{c}{ Kandungan } & Jumlah \\
\hline Kalori & $122 \mathrm{kal}$ \\
Karbohidrat & $29 \mathrm{gram}$ \\
Lemak & $1 \mathrm{gram}$ \\
Protein & $6 \mathrm{gram}$ \\
Kalsium & $100 \mathrm{mg}$ \\
Fosfor & $100 \mathrm{mg}$ \\
Besi & $3,3 \mathrm{mg}$ \\
Vitamin A & $107,5 \mathrm{SI}$ \\
Vitamiin B1 & $80 \mathrm{mg}$ \\
Vitamiin C & $17 \mathrm{mg}$ \\
Air & $66 \mathrm{gram}$ \\
\hline Sumber : Khasiat Cincau Perdu Setijo & $(2008, \mathrm{~lm} .19)$
\end{tabular}

Sumber : Khasiat Cincau Perdu, Setijo (2008, hlm. 19)

\section{Metode Penelitian}

Metode penelitian yang digunakan oleh penulis dalam penelitian ini adalah metode penelitian eksperimental yang merupakan penelitian yang termasuk dalam metode penelitian kuantitatif. Penelitian eksperimen dilakukan di laboratorium metode penelitian eksperimen dapat diartikan sebagai metode yang digunakan untuk mencari pengaruh perlakuan tertentu terhadap yang lain dalam kondisi yang terkendalikan (Sugiyono, 2011, hlm.109).

Pelaksanaan eksperimen digunakan sebagai tahap implementasi atau uji coba model pelatihan keterampilan usaha terpadu. Kajian penelitian yang digunakan dalam penelitian ini bersifat deskriptif analitik. Selain itu, dalam penelitian ini penulis melakukan uji organoleptik kepada panelis tentang inovasi produk bubuk cincau hijau. Kemudian melakukan uji daya terima konsumen dengan diberikan sampel dan kuisioner sebagai acuan analisis. Adapun teknik pengumpulan data yang penulis gunakan dalam penelitian ini adalah : wawancara, studi literatur, observasi, kuisioner, dokumentasi, dan eksperimental.

\section{Hasil dan Pembahasan}

Penulis telah melakukan penelitian inovasi produk Bubuk Cincau Hijau dengan hasil penelitian berupa standar resep, alur pembuatan, serta gambar inovasi Bubuk Cincau Hijau. Pembuatan bubuk cincau hijau diawali dengan mengumpulkan daun cincau hijau segar yang kemudian di cuci dan di keringkan hingga bersih. Setelah daun cincau dicuci bersih, dipotong menjadi bagian-bagian kecil, agar memudahkan proses pengeringan. Keringkan potongan daun cincau hijau dengan cara di sangrai dengan api sangat kecil sambil diaduk. Daun cincau yang telah kering dihaluskan menggunakan alat bantu miller, yang hasilnya kemudian disaring hingga menjadi bubuk-bubuk halus. Bubuk daun cincau kemudian dicampurkan dengan bubuk vanili, bubuk jeli, serta tepung pati jagung sesuai takarannya. Dicampurkan hingga 
merata, dan bubuk cincau hijau siap untuk diolah menjadi cincau hijau yang siap untuk dikonsumsi.

Perbandingan formula dalam penggunaan bahan pengental dalam pembuatan bubuk cincau hijau merupakan objek dari penelitian ini. Formulasi resep yang digunakan peneliti yaitu $40 \%$ dan $60 \%$ penggunaan bubuk pengental (bubuk jeli dan bubuk agar-agar) dari bubuk cincau hijau. Pengujian dilakukan dengan melalui 2 tahap, tahap pertama tahapan uji organoleptik dengan mengambil 15 orang panelis ahli yang terdiri dari akademisi kuliner, chef, serta pengusaha kuliner.

Panelis ahli melakukan uji organoleptik terhadap 4 produk bubuk cincau hijau dengan formulasi yang berbeda-beda yang hasilnya mendapatkan satu produk terbaik. Produk terbaik yang didapatkan, kemudian diiujikan di tahap kedua yaitu tahap uji daya terima konsumen. Pada uji daya terima konsumen ini produk terbaik dibandingkan dengan produk kontrol yang dilakukan kepada 100 orang responden konsumen yang berasal dari berbagai kalangan.

Tahap uji organoleptik dilakukan dengan memberikan 4 sampel produk yang memiliki perbedaan bahan pengental serta perbedaan formulasi penggunaannya. Dalam melakukan uji organoleptik, produk sampel disajikan kepada panelis ahli (dari kalangan yang memiliki pengetahuan dan pengalaman lebih di bidang kuliner). Dalam penelitian ini, perbandingan produk diberi kode BCHAA (Bubuk Cincau Hijau AgarAgar) \& BCHJ (Bubuk Cincau Hijau Jeli). Berikut kode perbandingan yang digunakan penulis dalam produk Bubuk Cincau Hijau :
a. BCHAA 1 : $40 \%$ bubuk agar- agar dari penggunaan bubuk cincau hijau
b. BCHAA 2 : $60 \%$ bubuk agar- agar dari penggunaan bubuk cincau hijau

c. BCHJ 1 : $40 \%$ bubuk jeli dari penggunaan bubuk cincau hijau d. BCHJ 2 : $60 \%$ bubuk jeli dari penggunaan bubuk cincau hijau

Uji organoleptik yang telah dilakukan peneliti mendapatkan hasil bahwa produk BCHJ 2 lebih disukai oleh panelis ahli sehingga memperoleh nilai rata-rata sebanyak 25, dibandingkan dengan BCHJ 1 yang memperoleh nilai rata-rata 24.13, serta BCHAA 1 \& 2 yang keduanya memiliki nilai rata-rata 23 dan 23.07. Pada uji organoleptik ini juga peneliti mendapatkan saran dari salah satu panelis ahli yaitu Chef Teguh, yang memberikan saran dalam tahap pengeringan untuk mengikuti proses pengeringan daun teh, agar hasil bubuk tidak meninggalkan aroma daun kering namun tetap mempertahankan warna dan rasa khas dari daun cincau.

Setelah didapatkan hasil sampel produk terbaik di tahapan uji organoleptik, selanjutnya yaitu tahapan kedua, uji daya terima konsumen. Di tahapan yang kedua ini, dilakukan penilaian dari 100 orang responden dengan cara mencicipi dan memberikan penilaiannya mengenai daya terima sebagai konsumen, terhadap sampel produk terpilih, BCHJ1 yang dibandingkan dengan produk kontrol ke dalam kuisioner yang disediakan sebelumnya oleh peneliti.

Tahap uji daya terima konsumen ini dilakukan setelah mendapatkan hasil produk terbaik dari panelis ahli pada tahapan sebelumnya. Didapatkan produk BCHJ1 yang menjadi produk terbaik ini akan di uji kepada 100 responden dengan produk pembanding yaitu produk kontrol. Dari hasil pembandingan diketahui bahwa produk BCHJ1 memiliki nilai yang lebih besar yaitu sebesar 1581 dibandingkan dengan produk kontrol yang mendapatkan nilai 1521. Dan untuk nilai keseluruhan $\mathrm{BCHJ} 1$ sebesar 3119 (penilaian dalam bentuk cincau dan bubuk).

Selanjutnya dalam menghitung harga jual atau selling price beserta komposisinya seperti food cost (biaya bahan baku), labour cost (biaya tenaga kerja), overhead (biaya lain-lain), dan tentunya profit (keuntungan). Berikut ini adalah perhitungan atas 
komposisi harga jual produk :

Tabel 3. Komposisi Selling Price Bubuk Cincau Hijau

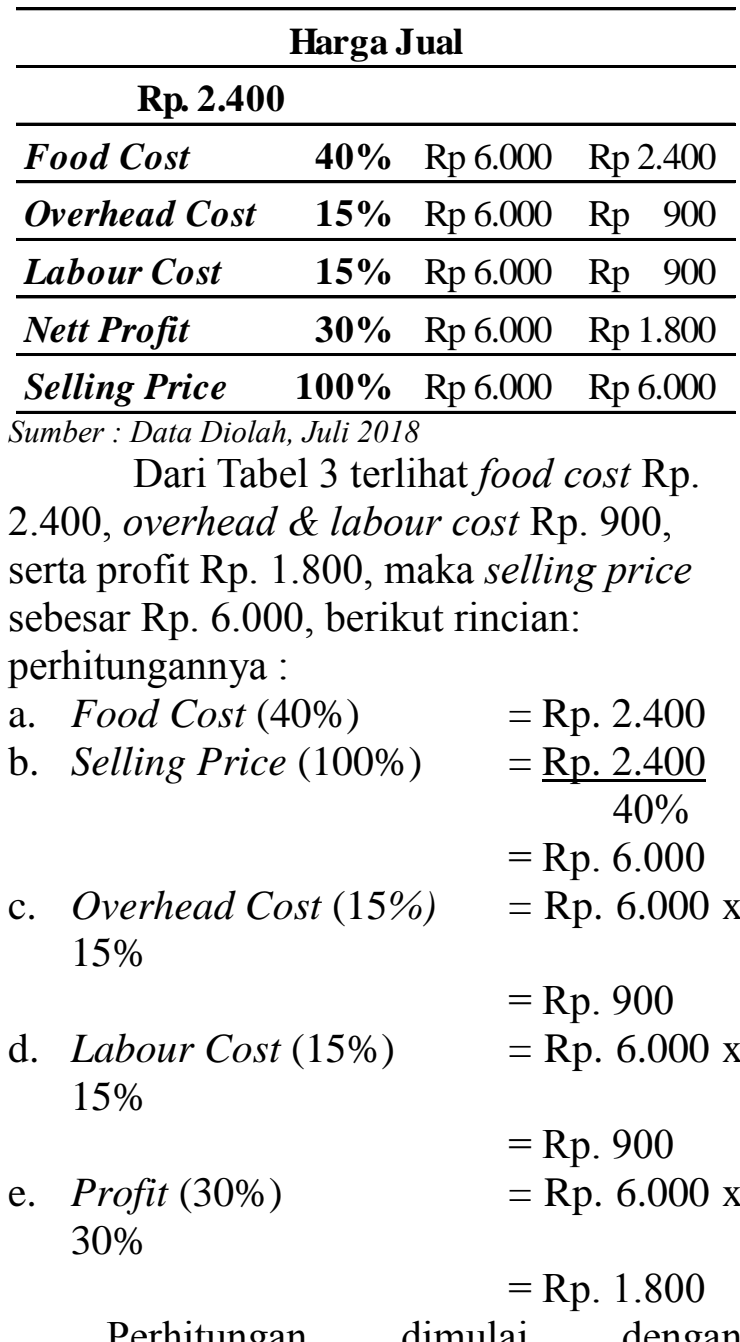

diketahuinya food cost yang juga adalah harga pokok atau bahan baku, guna memudahkan perhitungannya maka dihitung pertama adalah selling price, yang kemudian akan memudahkan perhitungan biaya yang lainnya. Yang menghasilkan hasil jual bubuk cincau hijau per sachet adalah Rp. 6.000 sesuai dengan harapan responden.

\section{Kesimpulan}

Hasil penelitian yang telah peneliti lakukan telah dijelaskan pada bab sebelumnya mengenai inovasi produk bubuk cincau hijau yang berbeda dari produk cincau hijau yang ada. Berikut adalah kesimpulan peneliti mengenai hasil penelitian inovasi produk bubuk cincau hijau berbasis daya terima konsumen :

Empat formulasi yang diujikan panelis ahli dalam uji organoleptik adalah empat formulasi bubuk cincau hijau dengan kode BCHAA 1 yaitu bubuk cincau hijau dengan tambahan $40 \%$ bubuk agar-agar, BCHAA 2 yaitu bubuk cincau hijau dengan tambahan $60 \%$ bubuk agar-agar, BCHJ1 yaitu bubuk cincau hijau dengan tambahan $40 \%$ bubuk jeli, dan BCHJ2 yaitu bubuk cincau hijau dengan tambahan $60 \%$ bubuk jeli.keempat formulasi tersebut diujikan kepada 15 panelis ahli di bidang kuliner untuk menilai mulai dari kesesuaian rasa, aroma, tekstur, hingga warna cincau yang dihasilkan dai bubuk cincau hijau. Hasilnya satu produk terbaik yang dipilih oleh rata-rata panelis ahli adalah produk BCHJ1 dengan rata-rata nilai 25, sedangkan BCHAA1 23, BCHAA2 23.07, dan $\mathrm{BCHJ} 2$ dengan total rata-rata 24.13

Tahapan uji daya terima konsumen yang dilakukan peneliti untuk menilai daya terma konsumen terhadap produk terpilih sebelumnya, BCHJ1 kepada 100 panelis konsumen dengan perbedaan latar belakang mulai dari jenis kelamin, usia, jenis pekerjaan, hingga beragam jenis latar belakang pendidikan terakhir. Penilaian yang meliputi rasa, aroma, teksur, warna, dan penampilan kemasan bubuk cincau hijau ini menghasilkan nilai 3119 untuk produk BCHJ1 yang mana nilai tersebut berada pada kelas interval 2721 - 3360 yang menyatakan bahwa produk diterima oleh konsumen.

Harga jual produk bubuk cincau hijau yang diharapkan panelis konsumen adalah Rp. 6.000/sachet dengan berat bersih 200 grm. Memiliki food cost Rp. 2.400, labour dan overhead masing-masing Rp. 900 serta profit sebesar Rp. 1.800, sehingga menghasilkan harga jual produk bubuk cincau hijau ini adalah Rp. 6.000.

\section{Daftar Rujukan}

Dhewanto, Wawan . (2014). Manajemen Inovasi. Yogyakarta: CV ANDI 


\section{OFFSET}

Hariana, Arief. (2013). 262 Tumbuhan Obat dan Khasiatnya. Jakarta : Penebar. Swadaya

Pitojo, S. (2008). Khasiat Cincau Perdu. Yogyakarta : Kanisius

Pitojo, S., \& Sumiati. (2005). Cincau : Cara Pembuatan dan Variasi Olahannya. Jakarta : Agromedia Pustaka.

Sugiyono. (2011). Metode Penelitian Kuantitatif, Kualitatif dan $R \& D$. Bandung: Alfabeta. 